\title{
ANALISIS PERSEPSI GURU SD KOTA MALANG TERHADAP KANDUNGAN MI PADA BUKU SISWA KURIKULUM 2013
}

\author{
Maharani Putri Kumalasani $^{1)}$, Dian Ika Kusumaningtyas ${ }^{2)}$ \\ Universitas Muhammadiyah Malang \\ e-mail: maharani@umm.ac.id ${ }^{1}$, dianikakusumaningtyas@umm.ac.id
}

\begin{abstract}
This study aims to describe the perception of elementary school teachers in Malang City on the multiple intensity content of the 2013 curriculum student's book. The research method used in this study is to use a qualitative approach with qualitative descriptive method. The data collection tool in this study was the interview instrument and questionnaire analysis of Multiple Intelligence content in the 2013 curriculum students 'books. The results of this study were that the analysis conducted by the teacher showed that there were Multiple Intelligences in the students' books, especially on student activities. The eight intelligences include linguistic, spatial, kinesthetic, interpersonal, intrapersonal, logical mathematical, musical, and naturalist intelligence. These eight intelligences do not always appear simultaneously. There is intelligence that dominates the student's book. Because student books are the main source during the learning process, to maximize the intelligence that is available to the teacher's students, they respond to the addition of activities that are expected to maximize students' intelligence in a balanced manner. This is a positive perception shown by the teacher.
\end{abstract}

Keyword: student books, multiple intelligences, teacher perceptions.

\begin{abstract}
Abstrak: Penelitian ini bertujuan untuk mendeskrispsikan persepsi guru SD Kota Malang terhadap kandungan Multiple Intellegences pada buku siswa kurikulum 2013. Metode penelitian yang digunakan pada penelitian ini ialah menggunakan pendekatan kualitatif dengan metode deskriptif kualitatif. Alat pengumpul data dalam penelitian ini ialah instrument wawancara dan angket analisis kandungan Multiple Intellegences pada buku siswa kurikulum 2013. Hasil penelitian ini ialah analisis yang dilakukan oleh guru menunjukkan bahwa terkandung Multiple Intellegences pada buku siswa yang khususnya pada kegiatan siswa. Kedelapan kecerdasan itu antara lain kecerdasan linguistic, spasial, kinestetik, interpersonal, intrapersonal, logis matematis, musical, dan naturalis. Kedelapan kecerdasan tersebut tidak selalu muncul secara bersamaan. Terdapat kecerdasan yang mendominasi pada buku siswa tersebut. Karena buku siswa merupakan sumber utama pada saat proses pembelajaran, ntuk memaksimalkan kecerdasan yang ada pada diri siswa guru memberikan tanggapan terhadap penambahan kegiatan yang diharapkan dapat memaksimalkan kecerdasan siswa secara seimbang. Hal tersebut merupakan persepsi positif yang ditunjukkan oleh guru.
\end{abstract}

Kata kunci: buku siswa, multiple Intellegences, persepsi guru

\section{PENDAHULUAN}

Kurikulum 2013 merupakan kurikulum baru yang diterapkan di tingkat Sekolah Dasar. Kurikulum 2013 yang pada proses pembelajarannya ialah menerapkan pembelajaran tematik yang berkaitan tema pada tiap pembelajarannya. Sehingga dengan dipayungi oleh tema, maka dalam pembelajaran terdapat beberapa mata pelajaran diantaranya Bahasa Indonesia, PKn, IPA, IPS, SBDP, Matematika, dan PJOK. Pada 1 tema memuat 7 mata pelajaran. Namun saat ini ada mata pelajaran yang tidak dimasukkan dalam tema yaitu mata pelajaran Matematika dan PJOK. Sehingga ke dua mata pelajaran tersebut berdiri sendiri. Sumber belajar pada kurikulum 2013 ini disediakan oleh pemerintah yang berupa buku guru dan buku siswa.

Buku guru dan buku siswa merupakan sumber belajar utama yang digunakan pada kurikulum 2013. Namun guru diharapkan memiliki sumber belajar yang lain untuk menambah pengetahuan 
dan wawasan yang akan diberikan kepada guru dan pengetahuan tersebut juga memberikan wawasan yang lebih luas yang diperoleh guru. Buku guru merupakan buku yang didalamnya berupa langkah-lang untuk melaksanakan proses pembelajaran tematik kurikulum 2013. Sedangkan buku siswa berisi terkait kegiatan pembelajaran yang harus dilakukan oleh siswa yang diintegrasikan dengan buku guru. Setiap buku siswa memiliki tema yang didalamnya terdapat 3 subtema. Di dalam sub tema terdapat 6 pembelajaran yang diharapkan dalam 1 pembelajaran dilakukan dalam waktu 1 hari pada proses pembelajaran disekolah. Buku siswa yang dirancang dengan pendekatan saintifik untuk melatih siswa belajar secara mandiri dengan tahapantahapan yang dilalui sehingga cara belajar siswa menjadi sistematis dan proses pembelajaran menjadi bermakna yang berpusat pada siswa.

Proses pembelajaran bermakna tentunya didukung dengan beberapa factor tidak hanya satu sumber belajar yang diberikan oleh pemerintah yaitu buku siswa. Sumber belajar yang bervariasi akan menambah pengetahuan guru maupun siswa. Bagaimanapun proses pembelajaran yang diterapkan diharapkan dapat menjadikan siswa dapat mengasah kecerdasan yang dimiliki oleh siswa secara menyeluruh. Setiap siswa diilhami oleh kecerdasan yang sangat kompleks, dan kecerdasan itu harus diasah agar berkembang maksimal. Kecerdasan yang dimiliki oleh siswa jika dikembangkan akan dapat memberikan dampak yang positif. Dampak yang terjadi ialah kemampuan siswa yang dimaksimalkan akan menajadikan manusia yang memiliki kualitas yang tinggi.

Persepsi Guru terhadap kecerdasan yang dimiliki oleh siswa selama ini sama hanya kognitif yang diukur. Akan tetapi siswa memiliki kecerdasan yang beragam. Hal ini perlu adanya pengembangan secara maksimal. Untuk mengembangkan kecerdasan siswa menjadi maksimal merupakan tugas seorang guru di sekolah. Kecerdasan yang dimiliki oleh siswa diantaranya ialah kecerdasan linguistic, Kinestetik, matematis, inter personal, intra personal, natural, musical, dan visual/spasial. Kecerdasan linguistik berkaitan dengan kemampuan siswa dalam hal kemampuan berbicara dan membaca. Kecerdasan kinestetik berkaitan dengan kemampuan memaksimalkan daya motoric siswa. Kecerdasan matematis berkaitan dengan bagaimana menyeleseikan permasalahan secara sistematis dan menjawab soal dengan benar/salah. Kecerdasan interpersonal berkaitan dengan kemampuan dalam mengeksplor kemampuan diri siswa. Kecerdasan intrapersonal berkaitan dengan kemampuan siswa dalam berinteraksi dengan orang lain. Kecerdasan natural berkaitan dengan kemampuan menggali pengetahuan yang berkaitan dengan alam. Kecerdasan musical berkaitan dengan kemampuan siswa dalam hal yang berhubungan dengan musik. Kecerdasan spasial/visual berkitan dengan bagaimana melihat gambar dan menuangkan dalam bentuk visual. Kecerdasan siswa dalam proses pembelajaran memang tidak selalu nampak keseluruan, biasanya hanya nampak yang siswa lebih tinggi dalam kemampuannya tersebut. Sehingga disini ialah tugas guru untuk mengasah seluruh kecerdasan siswa berkembang secara maksimal.

SD Muhammadiyah 9 Malang salah satu SD yang menerapkan kurikulum 2013. Sumber belajar yang digunakan ialah Buku siswa yang dijadikan sumber belajar utama bagi siswa. Karena didalam buku siswa terdapat kegiatan yang harus dilakukan oleh siswa dalam proses pembelajaran. Dengan kegiatan yang ada di buku siswa diharapkan mendukung berkembangnya seluruh kecerdasan yang dimiliki oleh siswa. Namun hal itu masih belum diketahui apakah setiap kegiatan yang ada di buku siswa dapat 
mengembangkan kecerdasan siswa secara maksimal. Hal ini perlu adanya identifikasi untuk mengetahui kandungan Multiple Intellegences yang ada di buku siswa. Karena kegiatan tersebut akan mempengaruhi proses pembelajaran yang dapat mengembangkan kecerdasan siswa. Disini guru perlu untuk memberikan analisis terhadap kandungan MI yang ada di buku siswa khususnya pada kegiatan siswa.

\section{Persepsi Guru}

Persepsi Bimo Walgito (2004:70)

mengungkapkan bahwa persepsi merupakan suatu proses pengorganisasian, penginterpretasian terhadap stimulus yang diterima oleh organisme atau individu sehingga menjadi sesuatu yang berarti, dan merupakan aktivitas yang integrated dalam diri individu. Respon sebagai akibat dari persepsi dapat diambil oleh individu dengan berbagai macam bentuk. Stimulus mana yang akan mendapatkan respon dari individu tergantung pada perhatian individu yang bersangkutan. Berdasarkan hal tersebut, perasaan, kemampuan berfikir, pengalaman-pengalaman yang dimiliki individu tidak sama, maka dalam mempersepsi sesuatu stimulus, hasil persepsi mungkin akan berbeda antar individu satu dengan individu lain.

Dengan demikian persepsi merupakan proses perlakuan individu yaitu pemberian tanggapan, arti, gambaran terhadap apa yang dilihat, didengar, atau dirasakan oleh inderanya dalam bentuk sikap, pendapat, dan tingkah laku atau disebut sebagai perilaku individu. Persepsi merupakan suatu proses yang didahului oleh penginderaan, yaitu suatu rangsangan yang diterima oleh individu. Jadi persepsi guru terkait ini ialah persepsi tentang Multiple Intellegences yang ada pada kegiatan siswa yang ada di buku siswa pada Tema 1 Indahnya Kebersamaan kelas IV SD.

\section{Buku Siswa}

Kurikulum 2013 pelaksanaan pembelajarannya menggunakan buku siswa untuk mengemas setiap kegiatan pembelajaran setiap harinya dan didukung dengan buku guru. Kemendikbud (2013:3) menyatakan bahwa buku siswa adalah buku yang diperuntukkan bagi siswa yang dipergunakan sebagai panduan aktifitas pembelajaran untuk memudahkan siswa dalam menguasai kompetensi tertentu. Berdasarkan pengertian buku siswa yang dijelaskan oleh Kemendikbud dapat disimpulkan bahwa buku siswa merupakan buku yang digunakan siswa dalam proses pembelajaran, berfungsi sebagai panduan aktivitas belajar untuk membantu siswa mempermudah menguasai kompetensi tertentu.

Buku siswa selain digunakan sebagai buku bacaan, buku siswa juga berisi kegiatan-kegiatan yang akan dilakukan selama proses pembelajaran. Isinya dirancang dengan dilengkapi dengan contoh kegiatan dengan tujuan dapat terlaksananya pembelajaran kontekstual, sehingga siswa dapat mempelajari dan menerapkan sesuatu yang relevan dengan dikehidupan seharihari yang dialaminya. Buku siswa disusun untuk memfasilitasi siswa agar mendapatkan pengalaman belajar yang bermakna dan aktif dalam pembelajarannya, kebermaknaan dan keaktifan itu diterapkan melalui kegiatan mengamati, menanya, menalar, mencoba, berdiskusi serta meningkatkan kemampuan berkomunikasi baik antar teman maupun dengan gurunya. Melalui kegiatan-kegiatan tersebut diharapkan dapat menumbuhkan motivasi, rasa keiingintahuan, inisiatif, dan kreatifitas peserta didik.

Multiple Intellegences

Multiple Intellegences adalah cara seseorang untuk dapat berpikir dan bertindak dalam memecahkan masalah menggunakan kecerdasan-kecerdasan 
yang dimilikinya. Armstrong (2009:15) mengemukakan bahwa setiap orang memiliki minimal delapan kecerdasan, dimana semua kecerdasan tersebut berfungsi secara bersama-sama dengan cara yang unik bagi setiap orang. Hal ini sependapat dengan Gardner (dalam Thobroni, 2013: 239) yang menjelaskan bahwa manusia tidak hanya menggunakan satu kecerdasan saja. Berbagai kecerdasan saling terkait dan kecerdasan yang paling menonjol akan mengendalikan kecerdasan lain dalam pemecahan masalah. Maksudnya, setiap manusia terkadang memiliki keunggulan pada salah satu kecerdasan dan kekurangan dalam kecerdasan lainnya. Meskipun begitu, antar kecerdasan saling mendukung dan melengkapi.

Gardner

mengelompokkan

(2013:6-7) kategori kecerdasan. Delapan kecerdasan tersebut yaitu:

\section{a. Kecerdasan visual/spasial}

Karakteristik kecerdasan spasial yaitu menikmati peta dan grafik, suka menggambar, membangun, membuat desain, dan menciptakan sesuatu, berpikir dalam tiga dimensi, menyukai memecahkan teka-teki, mencintai video dan foto, menikmati warna dan desain, menikmati pola dan geometri dalam matematika, menyukai menggambar. (Chatib dan Said, 2012:88)

\section{b. Kecerdasan verbal/linguistic}

Chatib \& Said (2012:82) mengatakan bahwa kecerdasan linguistik dapat dilakukan dengan hal-hal berikut seperti mendengar serta merespon setiap ritme, warna, dan berbagai ungkapan kata, meniru suara, bahasa, membaca, dan menulis dari orang lain, menyimak, membaca termasuk mengeja, menulis, dan diskusi, dan sebagainya

c. Kecerdasan logis matematis, Jasmine (2012:21) mengemukakan bahwa kecerdasan ini sering dipandang dan dihargai lebih tinggi dari pada kecerdasan lainnya. Amstrong (2003:20) menjelaskan bahwa kecerdasan logis-matematis melibatkan ketrerampilan mengolah angka atau kemahiran menggunakan logika atau akal sehat.

d. Kecerdasan musical/ritmik,

Kecerdasan musikal berkaitan dengan musik/ritmik. Hoerr dkk, (2010:172) menyatakan bahwa karakteristik dalam kecerdasan musikal yaitu suka bernyanyi dan memainkan alat musik, mengingat lagu dan melodi, menikmati, mendengarkan musik, meniru memukul irama, mengetahui suara dilingkungan, dapat membedakan pola suara, sensitif terhadap melodi dan nada, tubuh bergerak ketika musik diputar, serta memiliki pemahaman yang kaya struktur musik, irama, dan catatan.

\section{e. Kecerdasan kinestetik}

Kecerdasan kinestetik berkaitan dengan badan. Seseorang yang memiliki jenis kecerdasan ini menggunakan tubuhnya untuk memecahkan masalah, membuat sesuatu, dan menyampaikan ide-ide dan emosi. Selain itu siswa yang kuat dalam kecerdasan ini pandai kegiatan fisik, koordinasi tangan-mata, dan memiliki kecenderungan untuk bergerak, menyentuh sesuatu hal, dan sikap (Nicolson \& Nelson, 1998:11).

\section{f. Kecerdasan interpersonal/social)}

Kecerdasan interpersonal berkaitan dengan orang lain. Siswa dengan kecerdasan interpersonal menampakkan kegembiraan dalam berteman dan kesenangan dalam berbagai aktivitas social serta ketidaknyamanan atau keengganan dalam kesendirian dan menyendiri (Jasmine, 2012:26).

\section{g. Kecerdasan}

\section{intrapersonal/intropeksi}

Kecerdasan intrapersonal merupakan kecerdasan yang berhubungan dengan diri sendiri. Hoerr dkk (2010:42) 
menyatakan bahwa karakteristik kecerdasan intrapersonal yaitu mengejar kepentingan pribadi, menetapkan tujuan yang realistis, mengidentifikasi perasaan, merasakan kekuatan dan kelemahan diri sendiri, percaya diri dalam kemampuan mereka, melamunan, yang mendalam dan reflektif, intuitif, mengikuti naluri mereka, merasa nyaman dengan diri mereka sendiri, mengungkapkan rasa keadilan

h. Kecerdasan naturalis

Kecerdasan naturalistik berkaitan dengan hewan dan tumbuhan. Baum dkk. (2005:19), menyatakan bahwa "kecerdasan naturalis menunjukkan kemampuan manusia untuk membedakan antara makhluk hidup (tanaman, hewan) serta kepekaan terhadap fitur lain dari dunia alam." Sejalan dengan pernyataan tersebut, Armstrong (2003:14) mengemukakan bahwa "kapasitas untuk mengenali dan mengklasifikasikan banyak spesies flora dan fauna di lingkungan seseorang (serta fenomena alam seperti gunung dan awan), dan kemampuan untuk merawat, menjinakkan, atau berinteraksi secara halus dengan makhluk hidup, atau dengan seluruh ekosistem."

\section{METODE}

Pendekatan penelitian yang digunakan ialah penelitian kualitatif menggunakan metode deskriptif kualitatif. Penelitian kualitatif menurut Moleong (2014:6) mengemukakan bahwa penelitian untuk melihat fenomena yang terjadi terkait hal-hal apa saja yang dialami oleh subjek penelitian seperti motivasi, perilaku, tindakan dll. Menurut Nazir (2011:54) penelitian deskriptif bertujuan untuk mendeskripsikan suatu kondisi atau sistem pemikiran secara sistematis, akurat, dan factual yang berkaitan dengan fakta, sifat, serta hubungan antar fenimena. Oleh karena itu metode deskriptif digunakan untuk mendiskripsikan gambaran Multiple Intellegencespada kegiatan siswa yang ada pada buku siswa kurikulum 2013 secara spesifik yang dilakukan oleh guru.

Sumber data yang ada pada penelitian ini yaitu guru dan buku siswa kurikulum 2013 kelas IV SD tema 1 "Indahnya Kebersamaan". Bentuk data dalam penelitian ini ialah data kualitatif yang diperoleh dari instrument hasil analisis guru terhadap Multiple Intellegences pada kegiatan siswa yang ada pada buku siswa. Teknik pengumpulan data yang digunakan dalam penelitian ini yaitu wawancara dan instrumen hasil analisis guru.

Dalam penelitian ini peneliti melakukan wawancara yang bersifat terbuka kepada informan namun dilakukan secara informal. Pertanyaan diberikan secara bebas namun terarah. Dalam penelitian ini, peneliti akan melakukan wawancara kepada guru kelas SD mengenai persepsi guru pendidikan khusus terhadap buku guru dan buku siswa dalam kurikulum 2013.

Dalam penelitian ini angket yang digunakan adalah angket terbuka, karena peneliti mengharapkan responden untuk menuliskan jawabannya berbentuk uraian yang seluasluasnya tentang suatu hal. Dengan kata lain, peneliti tidak menggiring responden untuk memberikan jawaban tertentu. Angket diberikan kepada guru kelas SD, karena peniliti ingin memperoleh informasi tentang persepsi guru pendidikan khusus terhadap buku guru dan buku siswa dalam kurikulum 2013 bagi peserta didik berkebutuhan khusus

Data dalam penelitian ini dianalisis dengan cara menelaah hasil analisis guru terhadap Multiple Intellegences dalam kegiatan siswa yang ada pada buku siswa, melakukan penarikan kesimpulan dari data yang diperoleh.

Analisis data adalah proses mencari dan menyusun secara sistematis data yang diperoleh dari wawancara,cacatan 
lapangan,dan dokumentasi, dengan cara mengorganisasikan data kedalam kategori,menjabarkan kedalam unitunit,melakukan sintesis,menyusun kedalam pola,memilih mana yang penting dan yang akan dipelajari dan membuat kesimpulan. Analisis data dalam penelitian kualitatif dilakukan sejak sebelum memasuki lapangan,selama dilapangan,dan setelah selesai dilapangan. Menurut Nasution (dalam Sugiono, 2010:245) "Analisis telah mulai sejak merumuskan dan menjelaskan masalah,sebelum terjun kelapangan,dan berlangsung terus sampai penulisan hasil penelitian."

Kegiatan dalam analisis data dalam penelitian ini, yakni pertama, kegiatan reduksi data (data reduction), pada tahap ini peneliti memilih hal-hal yang pokok dari data yang didapat dilapangan, merangkum, mengfokuskan pada hal-hal yang penting dan dicari polanya. Proses reduksi ini dilakukan secara bertahap, selama dan setelah pengumpulan data, sampai laporan hasil. Penulis memilah-milah data yang penting berkaitan dengan fokus penelitian dan membuat kerangka penyajiannya. Kedua, penyajian data (data display), setelah mereduksi data, maka langkah selanjutnya adalah mendisplay data. Didalam kegiatan ini, penulis menyusun kembali data berdasarkan klasifikasi dan masingmasing topik kemudian topik yang sama disimpan dalam satu tempat, masingmasng tempat dan diberi tanda, hal ini untuk mempermudahkan dalam penggunaan data agar tidak terjadi kekeliruan. Ketiga, data yang dikelompokkan pada kegiatan kedua kemudian diteliti kembali dengan cermat, dilihat mana data yang telah lengkap dan data yang belum lengkap dan masih memerlukan data tambahan, dan kegiatan ini dilakukan pada saat kegiatan berlangsung. Keempat, setelah data dianggap cukup dan telah sampai pada titik jenuh atau telah memperoleh kesesuaian, maka kegiatan yang selanjutnya yaitu menyusun laporan hingga pada akhir pembuatankesimpulan.

Analisis data dalam penelitian kualitatif menggunakan metode induktif. Penelitian ini tidak menguji hipotesis (akan tetapi hipotesis kerja hanya digunakan sebagai pedoman) tetapi lebih merupakan penyusunan abstraksi berdasarkan data yang disimpulkan. Analisis dilakukan lebih intensif setelah semua data yang diperoleh di lapangan sudah memadai dan cukup, untuk diolah dan disusun menjadi hasil penelitian sampai dengan tahap akhir yakni kesimpulan penelitian.

\section{HASIL DAN PEMBAHASAN Hasil Penelitian}

Selain peneliti yang melakukan analisis kegiatan siswa pada buku siswa, peneliti juga meminta guru kelas IV untuk menganalisis kegiatan siswa pada buku siswa yang memunculkan kecerdasan di setiap kegiatan dan memberikan kecerdasan yang dapat dimaksimalkan dalam kegiatan pembelajaran. Hal ini dilakukan untuk mendukung data penelitian dalam menganalisis buku siswa.

Kegiatan siswa yang dianalisis oleh guru yang memiliki tanda yang berupa ajakan seperti AYO MEMBACA, AYO BERLATIH, AYO MENGAMATI, AYO MENCOBA, AYO RENUNGKAN, AYO BERKREASI, AYO BERDISKUSI, AYO MENULIS, dan AYO MEMBACA. Dari kegiatan tersebut akan dianalisis kecerdasan apa yang muncul dan kemudian guru memberikan kecerdasan yang dapat dimaksimalkan dari kegiatan siswa melalui kegiatan pembelajaran.

\section{SUBTEMA 1}

Hasil analisis pada subtema 1 "Keberagaman Budaya Bangsaku", yang memiliki kegiatan ajakan sebanyak 23 kegiatan. Kegiatan tersebut tidak memunculkan semua kecerdasan, hanya 5 
kecerdasan yang dimunculkan seperti : Kecerdasan Linguistik berjumlah 3 kegiatan, Visual berjumlah 11 kegiatan, Interpersonal berjumlah 5 kegiatan, Kinestetik berjumlah 2 kegiatan, dan Intrapersonal berjumlah 5 kegiatan. Kecerdasan yang sering muncul ialah kecerdasan Visual, sedangkan kecerdasan yang jarang muncul ialah kecerdasan Kinestetik. Kecerdasan yang tidak muncul berjumlah 3 kecerdasan seperti: Kecerdasan Logis Matematis, Musikal, dan Naturalis. Guru dalam menganalisis tentunya berdasarkan kegiatan pada buku siswa yang menghasilkan 5 kecerdasan yang muncul. Berdasarkan hasil tersebut, guru ingin memunculkan dan memaksimalkan kecerdasan yang belum muncul dan belum maksimal, dengan menambahkan kegiatan yang berhubungan dengan kegiatan yang ada pada buku siswa.

Kecerdasan yang dapat dimaksimalkan pada kegiatan pada buku siswa subtema 1 sesuai dengan hasil analisis guru ialah kecerdasan: Intrapersonal, Linguistik, Kinestetik, Visual, Interpersonal, Logis Matematis, dan Musikal. Dengan memaksimalkan kecerdasan tersebut didukung dengan kegiatan pembelajaran yang dilakukan oleh guru. Penambahan kegiatan akan memberikan inovasi yang efektif dalam proses pembelajaran sehari-hari yang dapat menyeimbangkan kecerdasan yang dimiliki oleh siswa.

\section{SUBTEMA 2}

Hasil analisis pada subtema 2 "Kebersamaan dalam Keberagaman", yang memiliki kegiatan ajakan sebanyak 22 kegiatan. Kegiatan tersebut memunculkan semua kecerdasan, seperti : Kecerdasan Linguistik berjumlah 4 kegiatan, Visual berjumlah 18 kegiatan, Interpersonal berjumlah 7 kegiatan, Kinestetik berjumlah 8 kegiatan, Musikal berjumlah 1 kegiatan, Naturalis berjumlah 3 kegiatan, Logis Matematis berjumlah 3 kegiatan dan Intrapersonal berjumlah 7 kegiatan. Kecerdasan yang sering muncul ialah kecerdasan Visual, sedangkan kecerdasan yang jarang muncul ialah kecerdasan Kinestetik. Kecerdasan yang tidak muncul berjumlah 3 kecerdasan seperti: Kecerdasan Logis Matematis, Musikal, dan Naturalis. Guru dalam menganalisis tentunya berdasarkan kegiatan pada buku siswa yang menghasilkan 8 kecerdasan yang muncul. Berdasarkan hasil tersebut, guru ingin memaksimalkan kecerdasan yang sudah muncul, dengan menambahkan kegiatan yang berhubungan dengan kegiatan yang ada pada buku siswa.

Kecerdasan yang dapat dimaksimalkan pada kegiatan pada buku siswa subtema 2 sesuai dengan hasil analisis guru ialah kecerdasan: Intrapersonal, Linguistik, Kinestetik, Visual, Interpersonal, Logis Matematis, Naturalis dan Musikal. Dengan memaksimalkan kecerdasan tersebut didukung dengan kegiatan pembelajaran yang dilakukan oleh guru. Penambahan kegiatan akan memberikan inovasi yang efektif dalam proses pembelajaran seharihari yang dapat menyeimbangkan kecerdasan yang dimiliki oleh siswa.

\section{SUBTEMA 3}

Hasil analisis pada subtema 3 "Bersyukur Atas Keragaman", yang memiliki kegiatan ajakan sebanyak 24 kegiatan. Kegiatan tersebut tidak memunculkan semua kecerdasan, hanya 6 kecerdasan yang dimunculkan seperti : Kecerdasan Linguistik berjumlah 1 kegiatan, Visual berjumlah 7 kegiatan, Interpersonal berjumlah 3 kegiatan, Kinestetik berjumlah 3 kegiatan, Logis Matematis berjumlah 3 kegiatan dan Intrapersonal berjumlah 7 kegiatan. Kecerdasan yang sering muncul ialah kecerdasan Visual dan Intrapersonal, sedangkan kecerdasan yang jarang muncul ialah kecerdasan Linguisti, Interpersonal, Kinestetik, dan Logis Matematis. Kecerdasan yang tidak muncul berjumlah 2 kecerdasan seperti: Kecerdasan Musikal, dan Naturalis. Guru dalam menganalisis tentunya 
berdasarkan kegiatan pada buku siswa yang menghasilkan 6 kecerdasan yang muncul. Berdasarkan hasil tersebut, guru ingin memunculkan dan memaksimalkan kecerdasan yang belum muncul dan belum maksimal, dengan menambahkan kegiatan yang berhubungan dengan kegiatan yang ada pada buku siswa.

Kecerdasan yang dapat dimaksimalkan pada kegiatan pada buku siswa subtema 3 sesuai dengan hasil analisis guru ialah kecerdasan: Intrapersonal, Linguistik, Kinestetik, Visual, Interpersonal, dan Intrapersonal. Dengan memaksimalkan kecerdasan tersebut didukung dengan kegiatan pembelajaran yang dilakukan oleh guru. Penambahan kegiatan akan memberikan inovasi yang efektif dalam proses pembelajaran sehari-hari yang dapat menyeimbangkan kecerdasan yang dimiliki oleh siswa.

\section{Pembahasan}

Berdasarkan hasil analisis guru terhadapat buku siswa menunjukkan buku siswa memiliki kegiatan yang berupa aktifitas yang dilakukan oleh siswa selama proses pembelajaran yang dapat mengasah kecerdasan siswa. Hal ini seperti yang terkandung dalam Kemendikbud (2013:3) menyatakan bahwa buku siswa adalah buku yang diperuntukkan bagi siswa yang dipergunakan sebagai panduan aktifitas pembelajaran untuk memudahkan siswa dalam menguasai kompetensi tertentu

Sesuai hasil penelitian terkait analisis guru terhadap Multiple Intellegences yang ada pada buku siswa menunjukan kedelapan kecerdasan ada pada buku siswa namun tidak semua kecerdasan muncul pada saat yang bersamaan. Pada setiap subtema menunjukkan adanya kecerdasan yang dominan dan ada kecerdasan yang jarang muncul yang dihasilkan dari analisis guru. Selain itu pada setiap subtema tidak semua kecerdasan muncul pada kegiatan siswa.
Hasil analisis tersebut menunjukkan bahwa pada buku siswa mengandung ke delapan Multiple Intellegences yang diintegrasikandalam kegiatan siswa. Hal ini menunjukkan bahwa kedelapan kecerdasan yang ada pada diri anak itu ada dan harus dikembangkan. Hal ini sepaham dengan pendapatnya Gardner (2013:6-7) mengelompokkan kemampuan-kemampuan manusia ke dalam delapan kategori kecerdasan.

Kecerdasan yang ada pada diri siswa diasah agar dapat berkembang dengan maksimal. Setiap kecerdasan tersbut akan memberikan stimulus kepada kecerdasan yang lainnya agar dapat berkembang secara bersama.sama dengan cara yang berbeda pada setiap siswa. Hal ini sependapat dengan Armstrong (2009:15) mengemukakan bahwa setiap orang memiliki minimal delapan kecerdasan, dimana semua kecerdasan tersebut berfungsi secara bersama-sama dengan cara yang unik bagi setiap orang.

Kecerdasan yang sesuai dengan hasil analisis yang dlakukan oleh guru menunjukkan terdapat kecerdasan yang dominan yang sering muncul dalam setiap kegiatan da nada kecerdasan yang jarang muncul pada kegiatan siswa. Walaupun ada kecerdasan dominan yang sering muncul namun kecerdasan yang lainnya muncul dari kecerdasan dominan tersebut. Hasil analisis tersebut sesuai dengan Gardner (dalam Thobroni, 2013: 239) yang menjelaskan bahwa manusia tidak hanya menggunakan satu kecerdasan saja. Berbagai kecerdasan saling terkait dan kecerdasan yang paling menonjol akan mengendalikan kecerdasan lain dalam pemecahan masalah.

Hasil analisis juga menunjukkan bahwa persepsi guru terhadap kecerdasan yang ada pada diri siswa harus dikembangkan dengan memberikan kegiatan yang dapat memunculkan kecerdasan yang jarang muncul pada buku siswa. Hal ini terbukti persepsi guru terhadap kecerdasan siswa itu dianggap 
penting untuk memaksimalkan kecerdasan dengan memberikan tambahan kegiatan yang dapat menciptakan kecerdasan yang seimbang pada siswa. Persepsi guru di SD Muhammadiyah 9 Malang dikatakan positif. Hal ini sependapat dengan apa yang dikatakan oleh Azwar (2002: 49) mengemukakan bahwa, skala sikap disusun untuk mengungkap sikap pro dan kontra, positif dan negatif, setuju dan tidak setuju terhadap suatu obyek sosial. Pernyataan sikap terdiri dari dua macam yaitu pernyataan favorable (mendukung atau memihak) dan pernyataan unfavorable (tidak mendukung/ tidak memihak) pada obyek sikap

\section{KESIMPULAN}

Guru menganalisis adanya kecerdasan Multiple Intellegences pada buku siswa yang dikhususkan pada kegiatan siswa. Hasil analisis tersebut menunjukkan bahwa Multiple Intellegences terdapat pada kegiatan siswa namun munculnya tidak bersamaan pada suatu kegiatan. Kedelapan kecerdasan itu anatara lain kecerdasan linguistic, spasial, kinestetik, interpersonal, intrapersonal, logis matematis, musical, dan naturalis Nampak terdapat kecerdasan yang mendominasi dalam buku siswa sehingga kecerdasan lainnya jarang di dimunculkan.

Dari hasil tersebut maka persepsi guru sangat positif untuk membuat semua kecerdasan yang ada pada buku siswa dapat dikembangkan secara maksimal dengan memberikan tanggapan penambahan kegiatan pada buku siswa untuk memaksimalkan kecerdasan siswa. Karena buku siswa merupakan sumber belajar utama yang digunakan oleh siswa dalam proses pembelajaran.
DAFTAR PUSTAKA

Armstrong, Thomas.2009. Multiple Intellegences in The Classroom. Alexsandria: $A S C D$

Armstrong, Thomas.2013. Kecerdasan Multiple di Dalam Kelas. Jakarta : PT Indeks. article /view/15458), diakses 14 Oktober 2016

Baum, Susan dkk. 2005. Multiple Intellegences In the Elementary Classroom A Teacher's Toolkit. New York \& London: Colombia University.

Chatib, Munif \& Said, Alamsyah. 2012. Sekolah Anak-Anak Juara : Berbasis Kecerdasan Jamak dan pendidikan Berkarakter. Bandung: PT Mizan Pustaka.

Gardner, Howard. 2003. Kecerdasan Majemuk (Multiple Intellegences) Teori dalam Praktek. Batam: Interaksara.

Hoerr, Thomas R dkk. 2010. Celebrating Every Learner: Activities and Strategies for Creating a Multiple Intellegences Classroom. San Francisco: Jossey Bass.

Jasmine, Julia. 2012. Metode Mengajar Multiple Intellegences: Membangkitkan Potensi Kecerdasan Siswa dalam Praktik Pembelajaran. Bandung: Nuansa Cendekia.

Sugiyono. 2013. Metode Penelitian Pendidikan. Bandung: Alfabeta. 